\title{
Crisis or Catharsis in Lead Isotope Analysis?
}

\section{Ernst Pernicka}

Max-Planck-Institut für Kernphysik, Postfach 1039 80, D-69029 Heidelberg, Germany

Since the nineteenth century, views on the possibility of determining the provenance of metal artefacts seems to have gone through periodic cycles like those of the economy. The introduction of a new analytical method is usually greeted with enthusiasm and high hopes. In the initial phase, new insights are provided and the solution of many problems seems to be near; some researchers and many observers begin to rely so heavily on one single technique and to neglect other lines of evidence - and sometimes even simple logic - that they have no hesitation in believing in odd conclusions. Two illustrative examples are Pittioni's repeated assertion (e.g., Neuninger et al. 1969) that most Late Bronze Age copper in central Europe derived from a rather small deposit (the so-called Berta-Grube) in the Tirol, despite the well-established Bronze Age copper mining in the much larger Mitterberg area and elsewhere, and Sangmeister's (1971) suggestion that arsenical copper was first produced in Iberia, whence it spread via the Aegean to the Balkans. This is usually the onset of a downward trend that can lead to frustration combined with a total condemnation of the once-hailed technique. Two decades ago this happened to trace element analysis by optical emission spectroscopy (Härke 1978).

Are we now witnessing the decline of lead isotope analysis too? This, at least, could be concluded from the article by Budd et al. (1995) on oxhide ingots and the Mediterranean metals trade. However, before we diagnose a crisis of method, we should consider the possibility that a research group is in crisis.

Ever since the early 1970s, when Noël Gale was invited by members of this Institute to collaborate with them in the investigation of ancient silver coins, there has been an increasing tendency to give the impression that lead isotope analysis in archaeology can only be performed and correctly interpreted at Oxford. There can be no doubt that Noël Gale and his wife, Zofia Stos-Gale, together with a few collaborators, have made important contributions to the development of early metallurgy, especially of the Aegean region; yet even in the early phases of their work, when it was mainly lead and silver objects that were being investigated, they tended to oversimplify complex results. One example was their conclusion that the majority of Early Cycladic lead and silver objects derived from only two sources, namely Siphnos and Laurion (Gale and Stos-Gale 1981b). This conclusion concurred nicely with the hypothesis, very popular in the 1970 s, that the remarkable cultural developments in the Cyclades during the third millennium $B C$ were initiated by technological innovations (Renfrew 1972). Closer 
inspection of the data revealed that only for one of the objects ascribed to Laurion by the Gales were the lead isotope ratios unambiguous (Pernicka and Wagner 1985). The conclusion reached by the Gales was mainly based on a relatively broad definition of the Laurion field, one that was later revised by the same authors without any comment (e.g. Gale and Stos-Gale 1992a). With this new definition of the Laurion field, they eliminated the basis of their archaeological conclusions drawn in 1981 that had marked the beginning of the general acceptance of the lead isotope technique.

Real enthusiasm was raised (Branigan 1982) when the method was applied by the Oxford team also to copper and copper alloys (Gale and Stos-Gale 1982). Error bars had long been abandoned in their lead isotope plots and their ore fields seemed to be very clearcut with the use of the third possible lead isotope ratio. Laurion was now identified not only as a source of lead and silver, but also of copper, in the Early Cycladic period. We demonstrated already some time ago that, again, their conclusions regarding the provenance of Eary Cycladic copper based on lead isotope ratios were by no means compelling (Pernicka et al. 1984). This article also included a warning that, for reasons of principle, it is safer to exclude certain deposits as possible sources than to make positive assignments. This view now seems to be shared even by the Gales, for they have adopted the 'exclusion principle' and their new Laurion field (noted above) does not encompass most of the Cycladic copper objects analyzed in 1982 . However, we have not yet heard any comment by them on the archaeological significance of this decisive change.

This behavioural pattern has been repeated in the investigation of the provenance of the oxhide ingots, and Budd et al. (1995) have to be thanked for their cumbersome work of going through the flood of publications by the Gales, with scattered and often repeated data, and of listing all the inconsistencies that have accumulated. It is time to realize that there is no unique isotopic fingerprint for Cypriot ore deposits, and thus for Cypriot copper. This was evident from the beginning for those who looked at the data without blinkers. Once the large spread of lead isotope ratios in the ores from the Arabah (Gale et al. 1990; Hauptmann et al. 1992) and from Sardinia became known, we should have abandoned all hopes of a unique lead isotope characteristic for any deposit in the eastern Mediterranean. Although discriminant function analysis seemingly allows the discrimination between two or three isotopically similar sources (Gale 1991; however, one would like to see error bars on such diagrams also), it is impossible to separate Cypriot from some Anatolian ores, even if all three possible lead isotope ratios are considered (Hauptmann et al. 1992). In response to the repeatedly published reproach (e.g., Gale and Stos-Gale 1992a) that we compare copper artefacts with ore fields composed of a mixture of copper and lead ores, we might remind the Gales that Laurion is the best example of just such a deposit. The Gales even go one step further and discuss the same mineralisation (the so-called Taurus $2 \mathrm{~A}$ source as isotopically defined by Yener et al. 1991) as a source for copper in one article (Gale 1991), and as a source for silver and lead in another one (StosGale and Macdonald 1991), both within the same volume. The experience from Rudna Glava shows that high uranium/lead ratios in the copper ores can further 
aggravate the problems with the lead isotope characteristic of copper ores (Pernicka et al. 1993). Thorough fieldwork and better mineralogical and geochemical descriptions of the respective mineralizations may improve the situation somewhat, but we have to realize that we have finally reached the point where one can only speak in terms of probabilities and not of firm assignments.

In this respect Budd et al. (1995) seem to throw out the baby with the bathwater, when they simply state that "...lead isotope analysis is unable to differentiate between Cyprus and Sardinia as a source for ingots", although the majority of data points are distinctly different for both regions. Since most of the oxhide ingots, especially the Sardinian ones, plot in the same area as most of the Cypriot ores, the probability is higher that they actually derive from Cyprus than from Sardinia, even if the centers of the ore and oxhide clusters do not quite coincide, as Muhly and Stech (1990) have already observed. In this context, it is probably better simply to disregard the erratic discussion on the real size of the Cypriot lead isotope field as well as the use of modern production figures as arguments for the dominance of Cyprus. The Gales had favourably considered the production of as little as 2000 tons of copper in 1955 for mainland Greece in support of Laurion (essentially a lead/zinc deposit) as a source for copper in the Late Bronze Age (Gale and Stos-Gale 1982), but elsewhere they regarded the production of 75,000 tons of copper over 100 years on Sardinia as "quite meagre" (Gale 1991). One possible way to differentiate between the two possible source regions is the use of trace element data.

It is self-evident that the combination of lead isotope with trace element data provides more variables for discrimination between different mineralizations than is capable with either data set alone. Incidentally, this combined approach was also pioneered by the Heidelberg/Mainz group some years ago (Pernicka et al. 1984). The problem is that the trace element 'fingerprint' is much more oblique than the one based on lead isotopes. It does exist, nonetheless, and can be used with advantage in conjunction with lead isotope ratios, if the right elements are used (see e.g. Pernicka et al. 1993). This is not the place to discuss the information contained in trace element concentrations of metal objects. To sum up very briefly, however, the Gales are right that the relatively small and overlapping variations of gold and silver concentrations in Cypriot copper ores and many oxhide ingots from Sardinia provide additional evidence that these ingots actually derived from Cyprus; they would, of course, be wrong if they maintained that this was conclusive evidence (but, to the best of my knowledge, this has not happened).

The range of gold and silver concentrations in copper from Cyprus is also consistent with copper ores from the same island (Rapp 1982; the data in this reference have to be multiplied by a factor of 3 , because they give concentrations in chalcopyrite). In fact, it is somewhat unfortunate that only gold and silver have been used in this discussion so far. The arsenic, nickel, and cobalt concentrations in Sardinian oxhide ingots (Maddin and Merkel 1990) are all quite consistent with their respective ranges in Cypriot ores (Rapp 1982), and it may turn out that the relatively high selenium and tellurium contents reported in oxhide ingots (Rapp 1982; Gale 1991) could also be indicative. It remains to be seen whether they will 
provide a means of discriminating between ores from Cyprus and Sardinia that overlap isotopically, but from the general information that is available on Sardinian copper ores, one would expect higher concentrations of lead, silver, and probably arsenic and antimony as well, than in Cypriot copper ores. At least with regard to silver and lead, this is true for most copper samples from Sardinia that are either not oxhide ingots or have different lead isotope ratios from Cypriot ores (Maddin and Merkel 1990; Gale 1991). The present evidence from trace element data would thus corroborate the conclusion drawn from the lead isotope results. This is still no proof, for elimination of one source does not automatically confirm another one (Begemann et al. 1989). But now alternative sources that may be proposed have to fulfil more requirements than simply similar lead isotope ratios, and this will certainly reduce their number.

Budd et al. (1995) are beating a dead horse when they discuss gold/silver ratios in ore deposits. For the present discussion it is not necessary to assume that the gold/silver ratio is uniform within an ore deposit, and nobody has put forward this idea. The two elements are simply among those that go with the copper during the smelting process and are usually not added intentionally; within limits, therefore, they are useful indicators of the ore source. It happens that in Cypriot ores these two elements appear to be correlated, but this did not play any role in the discussion on the provenance of the copper. Gold and silver are not necessarily correlated in ore deposits, but such a correlation is also not impossible. In fact, it has also been observed in copper ores from Ergani Maden in Turkey (Seeliger et al. 1985), in an environment geologically similar to that on Cyprus. It is therefore wrong to conclude that the higher silver contents in some Sardinian artefacts (still in the range of $1 \%$ or below) are due to alloying or the fabrication process (Budd et al. 1995). Apart from the unanswered questions of which fabrication process this should be or why one should add less than $1 \%$ silver to copper, this cannot be deduced from the available data. The suggestion is obviously inspired by their refusal to accept that there should be any chemical relationship at all between ore deposits and finished products. This, again, is an extreme position, one that indiscriminately rejects the good with the bad.

The authors also maintain that the lead concentrations of the ore samples used to define the Cypriot ore field are an order of magnitude lower than artefacts with similar lead isotope ratios. There could be several reasons for this. The most obvious one is that the samples for lead isotope analysis consisted of rather pure sulfide minerals, while the artefacts were produced from ores mixed with gangue, flux materials, and fuel. Since the concentration of lead is very low in Cypriot copper ores, average crustal abundances of lead in the accompanying materials would suffice to increase the lead content of the smelted copper and could possibly also shift the lead isotope ratios. According to Tylecote (1982), it is likely that on Cyprus, the oxidized ores were smelted with the addition of manganeserich material, while the sulfide ores would have needed silica to flux their inherent high iron contents. The copper ores of the island are often associated with umbers, which are known to be relatively rich in manganese. Silica was also available in the form of leached gossan material and bleached lava (Constantinou 1982). Although it is likely that such materials, as 
well as the fuels, have the same lead isotopic composition, as has been argued (Gale and Stos-Gale 1982), it is by no means guaranteed. Therefore, slags and metal inclusions if available, and dateable, are even better materials to define the lead isotope field of a certain region than ores (Pernicka 1992). In this respect, it is certainly unwise to exclude umber samples from the definition of the Cypriot isotope field, as has been done lately (Gale and Stos-Gale 1992b; 1993). Such a practice leads only to confusion, apart from the fact that it is again in disagreement with arguments advocated by the same authors.

Budd et al. (1995) propose that mixing of scrap metal might explain the additional lead and go so far as to expand this idea into an alternative model. However, this requires either that the foreign ore sources have similar lead isotope and trace element patterns, or that their contribution to the pool of metal in circulation was very small. In the latter case, mixing is irrelevant; in the former, given the rather low lead contents in Cypriot ores, we have relatively strict boundary conditions that will keep the number of possible candidates small. As yet there is none in sight, but one cannot really exclude the possibility that they exist. Even if it is possible that oxhide ingots do not represent the product of one smelting charge, they are likely to be made of copper from one source, according to the present evidence, and their purity still favours their interpretation as primary products (i.e., copper that was smelted and possibly refined, but not alloyed).

This does not mean that one can rule out the idea that mixing had occurred in the Late Bronze Age. Quite to the contrary, there are so many archaeological indications of recycling of metals, and especially the addition of lead to copper and bronze in the Late Bronze Age, that one would hesitate to embark on a large analytical project of metal objects from this period to determine their provenance. This generally held view may have to be modified in the future (Rychner 1990), but there is no doubt that mixing was practised. Since in this case the information on provenance is lost, it would be desirable at least to identify mixing in the analytical data. For this purpose Pernicka et al. (1984) have proposed a method that requires two end members with clearly different chemical and isotopic compositions. In practice, it was used only to exclude the possibility that the large spread of lead isotope ratios, then observed for the first time in the Aegean, could have been caused by a simple mixing line of two reservoirs. In a model where scrap metal from many different sources is continually recycled, the method is no longer applicable, because one could always postulate a few additional end members to explain the whole space occupied by any group of lead isotope data. This caveat was not concealed by Pernicka et al. (1984), but it is usually dropped in citations of this method.

Is this the end of lead isotope analysis in archaeology? I do not think so; but the time of enthusiasm is over, and for those who do not care to read the arguments exchanged or who do not understand them, condemnation is at hand (see, e.g., Chippindale 1994). This is only a natural reaction to an over-zealous interpretation of analytical data that seemingly promised to provide secure knowledge in a field where we are only slowly groping our way forward (Cherry and Knapp 1991), Often archaeologists are blinded by the exactness of the analytical results themselves that seems to imply equal exactness in the conclusions derived therefrom. This is 


\section{Pernicka}

obviously not the case. Any archaeological evidence, be it from stratigraphy, typology, or physical measurements, is of course open to different interpretations. Archaeologists should not expect, and scientists should not pretend, to be able to provide secure knowledge or even evidence of superior quality. This basic rule of conduct has not always been observed in the specific area of lead isotope analysis in archaeology. Hopefully, enough researchers will realize that, if we have to go one step back after zealously jumping two steps forward, we have still moved one step forward. In this sense I consider the present discussion, as well as the one that recently took place in the journal Archaeometry, as a long-due catharsis that I hope will bring us back to discussions that are less aroused, but more productive. 


\section{Consolidated References}

\section{Gale and Stos-Gale, Hall, Sayre et al., Muhly, Pernicka}

Bachmann, H.-G.

1982 Copper smelting slags from Cyprus: review and classification of analytical data. In J.D. Muhly, R. Maddin and V. Karageorghis (eds), Early Metallurgy in Cyprus, 4000-500 BC, 143-52. Larnaca: Pierides Foundation.

1993 The archaeometallurgy of silver. In R. Francovich (ed.), Archeologia delle Attivit Estrattive e Metallurgiche, 487-95. Firenze: Edizioni all'tnsegna del Giglio.

Balthazar, Judith Weinstein

1990 Copper and Bronze Working in Early through Middle Branze Age Cyprus. Studies in Mediterranean Archaeology and Literature, Pocket-book 84. Jonsered: P. Áströms Förlag.

Barnes, I. L., W. T. Chase, L. L. Holmes, E. C. Joel, P. Meyers, and E. V. Sayre

1988 The rechnical examination, lead isotope determination, and elemental analysis of some Shang and Zhou Dynasty bronze vesseis. In Robert Maddin (ed.), The Beginning of the Use of Metals and Alloys, 296-306. Cambridge. MA: Massachusetts Institute of Technology Press.

Bass, G.F.

1973 Cape Gelidonya and Bronze Age maritime trade. In Orient and Occident: Festschrift for Cyrus H. Gordon, 29-38. Kevelaer: Verlag Butzon and Bercker.

Begemann, F., S. Schmitt-Strecker and E. Pernicka

1989 Isotopic composition of lead in early metal artefacts: results, possibilities, and limitations. In A. Hauptmann, E. Pernicka and G. A. Wagner (eds), Old Worid Archaeometallurgy. Det Anschnitt, Beiheft 7: 269-78. Bochum: Deutsches BergbauMuseum.

1992 The metal finds from Thermi III-V: a chemical and lead-isotope study. Studia
Troica 2: 219-39.

Begemann F., E. Pernicka and S. Schmitt-Strecker

1994 Metal finds from llipinar and the advent of arsenical copper. Anatolica 20: 203-19.

Berthoud, T.

1979 Étude par l'analyse et la modélisation de la filiation entre minerais de cuivre et objects archéologiques du Moyen Orient (IVe-III millénnaire). Unpublished Ph.D. dissertation, Université de Paris.

Branigan, $\mathrm{K}$.

1982 Lead isotopes and the Bronze Age metal trade. Nature 296: 701-2.

Brill, R. H. and W. R. Shields

1972 Lead isotopes in ancient coins. In E. T. Hall and D. M. Metcalf (eds), Methods of Chemical and Metallurgical Investigation of Ancient Coinage. Royal Numismatic Society Special Publication 8: 279-303. London: Royal Numismatic Society.

Budd, P., A.M. Pollard, B. Scaife and R.G. Thomas

1995 Oxhide ingots, recycling and the Mediterranean metals trade. Journal of Mediterranean Archaeology 8(1): 1-32.

Chippindale, C.

1994 Editorial. Antiquity 68: 1-9.

Cherry, J.F. and A.B. Knapp

1991 Quantitative provenance studies and Bronze Age trade in the Mediterranean: some preliminary reflections. In N.H. Gale (ed.), Bronze Age Trade in the Mediterranean. Studies in Mediterranean Archaeology 90: 92-119. Jonsered: P. Asströms Forilag.

Constantinou, $\mathrm{G}$.

1982 Geological features and ancient exploitation of the cupriferous sulphide orebodies of Cyprus, In J.D. Muhly, R. Maddin and V. Karageorghis (eds), Early Metallurgy in Cyprus 4000-500 B.C., 13-24, Larnaca: 
Pierides Foundation.

Craddock, P. T.

1976 The composition of the copper alloys used by the Greek, Etruscan and Roman civilizations: 1 . The Greeks before the Archaic period. Journal of Archaeological Science 3: 93-113.

1986 Report on the composition of bronzes excavated from a Middle Cypriot site at Episkopi Phaneromeni and some comparative Cypriot Bronze Age metalwork. In Stuatt Swiny, The Kent State University Expedition co Episkopi Phaneromeni. Studies in Meditertanean Archaeology 74(2): 153-58. Nicosia: P. Áströms Förlag.

Gale, N. H.

1989 Archaeometallurgical studies of Late Bronze age oxhide copper ingots from the Mediterranean region. In A. Hauptmann, E. Pernicka and G.A. Wagner (eds), Old World Archazometallurgy. Der Anschnitt Beiheft 7: 247-68. Bochum: Deutsches BergbauMuseum.

1991 Copper oxhide ingots: their origin and their place in the Bronze Age metals trade in the Mediterranean. In N. H. Gale (ed.), Bronze Age Trade in the Mediterranean. Studies in Mediterranean Archaeology 90: 197-239. Jonsered: Paul Åströms Förlag.

Gale, N.H., H.-G. Bachmann, B. Rothenberg, Z.A. Stos-Gale and R.F. Tylecote

1990 The adventitious production of iron in the smelting of copper. In B. Rothenberg (ed.), Researches in the Arabah 1959-1984, Vol. 2: The Ancient Metallurgy of Copper, 182-91. London: Institute for Archaeometallurgical Studies.

Gale, N.H., W. Gentner, and G.A. Wagner

1980 Mineralogical and Geographical Silver Sources of Archaic Greek Coinage. In D.M. Metcalf and W.A. Oddy (eds), Metallurgy in Numismarics, Vol. 1: 3-49. London: Royal Numismatic Society.

Gale, N. H., E. T. C. Spooner, and P. J. Pott

1981 The lead and strontium isotope geochemistry of metalliferous sediments associated with Upper Cretaceous ophiolitic rocks in Cyprus, Syria, and the Sultanate of Oman. Canadian Journal of Earth Science 18:1290-1302.
Gale, N. H., and Z. A. Stos-Gale

1981a Ancient Egyptian silver. Joumal of Egyptian Archaeology 67: 103-15.

1981b Cycladic lead and silver metallurgy. Annwal of the British School at Athens76: 169-224.

1982 Bronze Age copper sources in the Mediterranean: a new approach. Science 216: 11-19.

1987 Oxhide ingots from Sardinia, Crete and Cyprus and the Bronze Age copper trade: new scientific evidence. In Miriam S. Balmuth (ed.), Studies in Sardinian Archaeology III: Nuragic Sardinia and the Mycenaean World. British Archaeological Reports, International Series 387: 135-77. Oxford: BAR.

1988 Recent evidence for a possible Bronze Age metal trade between Sardinia and the Aegean. In E. B. French and K. A. Wardle (eds), Problems in Greek Prehistory, 349-84. Bristol; Bristol Classical Press.

1992a Lead isotope studies in the Aegean (The British Acaderny Project). Proceedings of the British Academy 77: 63-108.

1992b Evaluating lead isotope data: comments on E.V. Sayre, K.A. Yener, E.C. Joel and L.L. Barnes, "Statistical evaluation of the presently accumulated lead isotope data from Anatolia and surrounding regions.... I". Archaeometry 34: 311-17.

1993 Comments on P, Budd, D. Gale, A.M. Pollard, R.G. Thomas and P.A. Williams, "Evaluating lead isotope data: further observations,...II". Archaeometry 35: 25259.

Hadjistavrinou, Y. and G. Constantinou.

1982 Cyprus. In F.W. Dunning, W. Mykura and D. Slater (eds), Mineral Deposits of Europe, Vol.2: 255-78. London: Institute of Mining and Metallurgy.

Härke, $\mathrm{H}$.

1978 Probleme der optischen Emissionsspektralanalyse in der Urgeschichtsforschung. Prahistorische Zetsschrift 53: 165276.

Hamelin, B., B. Duprè, O. Brévart and C. J. Allégre

1988 Metallogenesis at Paleo-spreading centers: lead isotope in sulfides, rocks and sediments from the Troodos Ophiolite (Cyprus). Chemical Geology 68: 229-38. 
Hauptmann, A., F. Begemann, E. Heitkemper, E. Pernicka, and S. Schmitt-Strecker

1992 Early copper produced at Feinan, Wadi Arabah, Jordan. Archeomateriais 6: 1-33.

Hauptmann, A., G. Weisgerber, and H.G.

Bachmann

1988 Early copper metallurgy in Oman. In Robert Maddin (ed.), The Beginning of the Use of Metals and Alloys, 34-52. Cambridge, MA: Massachusetts Institute of Technology Press.

Knapp, A.B.

1990 Cyprus, Crete and copper: a comment on Catling's paradox. Report of the Department of Antiquities, Cypris: 53-63.

Knapp, A.B., J.D. Muhly and P.M. Muhly

1988 To hoard is human: the metal deposits of LC IIC to LC III. Report of the Department of Antiquities, Cyprus: 233-62.

Lo Schiavo, F.

1990 Copper oxhide and plano-convex ingots in Sardinia. In F. Lo Schiavo, R. Maddin, J. Merkel, 1.D. Muhly and T. Stech (eds), Metallographic and Statistical Analyses of Copper Ingots from Sardinia. Soprintendenza ai Beni Culturali Archeologiche per le Provincie di Sassari e Nuoro, Quaderni 17: 16-40. Ozieri: Il Torchietto.

Lo Schiavo, F., E. Macnamara and L. Vagnetti.

1985 Late Cypriot imports to Italy and their influence on local bronzework. Papers of the British School at Rome 53: 1-71.

Lo Schiavo, F., T. Stech, R. Maddin and J. D. Mubly.

1987 Nuragic metallurgy in Sardinia: second preliminary report. In Miriam S. Balmuth (ed.), Studies in Sardinian Archaeology III: Nuragic Sardinia and the Mycenaean World. British Archaeological Reports, International Series 387: 179-219. Oxford: BAR.

Maddin, R.

1989 The copper ingots and tin ingots from the Kaş shipwreck. In A. Hauptmann, E. Pernicka and G.A. Wagner (eds), Old World Archaeometallargy. Der Anschnitt Beiheft 7: 99-105. Bochum: Deutsches BergbauMuseurn.

Maddin. R. and I. Merkel

1990 Metallographic and statistical observations.
In F. Lo Schiavo et al. (eds), Metallographic and Statistical Analyses of Copper Ingots from Sardinia. Soprintendenza ai Beni Culturali Archeologiche per le Provincie di Sassari e Nuoro, Quaderni 17: 42-199. Ozieri: II Torchietto.

Manning, S. W., and B. Weninger

1992 A light in the dark: archaeological wiggle matching and the absolute chronology of the close of the Aegean Late Bronze Age. Antiquity 66: 636-63.

Merkel, J.

1990 Experimental reconstruction of Bronze Age copper smelting. In B Rothenberg (ed.), Researches in the Arabah 1959-1984, Vol. 2: The Arcient Metallurgy of Copper, 78-122. London: Institute of Archaeology.

Muhly, J. D.

1980 Review of G. Rapp, Jr., and S. E. Aschenbrenner (eds), Excavations at Nichoria in Southwest Greece, Vol. I: Site, Environs and Techniques (Minneapolis; University of Minnesota Press, 1978), in American Joumal of Archaeology 84: 101102.

Muhly, J.D., R. Maddin and T. Stech.

1980 The oxhide ingots from Enkomi and Mathiati and Late Bronze Age copper smelting in Cyprus. Repart of the Department of Antiquities, Cyprus: 84-95.

1988 Cyprus, Crete and Sardinia: copper oxhide ingots and the Bronze Age metals trade. Report of the Deparment of Antiquities, Cyprus: 281-98.

Muhly, J.D. and T. Stech

1990 Metallographic and statistical observations. In F. Lo Schiavo et al. (eds), Metallographic and Statistical Analyses of Copper Ingots from Sardina. Soprintendenza ai Beni Culturali Archeologiche per le Provincie di Sassari e Nuoro, Quaderni 17: 201-222. Ozieri: I] Torchietto.

Nagamori, N. and P, J. Mackey

1978 Thermodynamics of copper matte converting: part II. Metallurgical Transactions 9B: 567-79.

Nagamori, N., P. J. Mackey, and P. Tarassoff

1975 Copper solubility in $\mathrm{FeO}-\mathrm{Fe} 2 \mathrm{O} 3-\mathrm{SiO}_{2}-$ A12O3 slag and distribution equilibria of $\mathrm{Pb}, \mathrm{Bi}, \mathrm{Sb}$, and $\mathrm{As}$ between slag and metallic 
copper. Metallurgical Transactions 6B: 295301.

Neuninger, H., R. Pittioni and E. Preuschen

1969 Salzburgs Kupfererzlagerstätten und Bronzefunde aus dem Lande Salzburg. Archaeologia Austriaca, Beiheft 9. Wien: Deuticke,

Pernicka, E.

1992 Evaluating lead isotope data: comments on E.V. Sayre, K.A. Yener, E.C. Joel and I.L. Barnes, "Statistical evaluation of the presently accumulated lead isotope data from Anatolia and surrounding regions..., III". Archaeometry 34: 322-26.

Pernicka, E., F. Begemann, S. Schmitt-Strecker and A. P. Grimanis

1990 On the composition and provenance of metal artefacts from Poliochni on Lemnos. Oxford Journal of Archaeology 9: 263-98.

Pernicka, E., F. Begemann, S. Schmitt-Strecker and G. A. Wagner

1993 Eneolithic and Early Bronze Age copper artefacts from the Balkans and their relation to Serbian copper ores. Prahistorische Zeitschrift 68: 1-54.

Pernicka, E., T.C. Seeliger, G.A. Wagner, F. Begernann, S. Schmitt-Strecker, C. Eibner, Ö. Oztunali, and I. Baranyi

1984 Archãometallurgische Untersuchungen in Nordwestanatolien. Jahrbuch des RömischGermanischen Zentralmuserms, Mainz 31: 533-99.

Pernicka, E. and G.A. Wagner

1985 Die metallurgische Bedeutung von Sifnos im Altertum. In G.A. Wagner and G. Weisgerber (eds), Silber, Blei und Gold auf Sifnos, Prähistorische und antike Metallproduktion. Der Anschnitt Beiheft 3: 200-11. Bochum: Deutsches BergbauMuseum.

Rapp, G., Jr

1982 Native copper and the beginning of smelting: chemical studies, In J.D. Muhly, R. Maddin and V. Karageorghis (eds), Early Metallurgy in Cyprus 4000-500 B.C., 33-38. Larnaca: Pierides Foundation.

Reedy, T. J. and C. L. Reedy

1992 Evaluating lead isotope data: comments on E.V. Sayre, K.A. Yener, E.C. Joel and I.L. Barnes, "Statistical evaluation of the presently accumulated lead isotope data from Anatolia and surrounding regions", ...IV. Archaeometry 34: 327-29.

Renfrew, C.

1972 The Emergence of Civilisation: The Cyclades and the Aegean in the Third Millennium B.C. London: Methuen.

1973 Before Civilization: The Radiocarbon Revolution and Prehistoric Europe. London: Jonathan Cape.

Rostoker, W., and M. Sadowski.

1980 The carbon reduction of fully oxidized chalcopyrite ores. Joumal of the Historical Metallurgy Society 14(1): 38-42.

Rychner, V.

1990 L'analyse chimique du bronze préhistoriques: pourquoi? Zeitschrift für Schweizerische Archäologie und Kunstgeschichte 47: 210-11.

Sangmeister, E.

1971 Aufkommen der Arsenbronze in SOEuropa. In M. Garasanin, A. Benac et N. Tasic (eds), Actes du VIIle Congrès International des Sciences Préhistoriques et Prothistoriques, Vol. I: 13I-38. Beograd: Union International des Sciences Préhistoriques et Protohistoriques.

Sayre, E. V., K. A. Yener, E. C. Joel and 1. L. Barnes

1992 Statistical evaluation of the presently accumulated lead isotope data from Anatolia and surrounding regions. Archaeometry 34: 73-105.

Schlitt, W. J. and K. J. Richards

1975 The distribution of silver, gold, platinum and palladium in metal-matte systerns. Metallurgical Transactions 6B: 237-43.

Seeliger, T.C., E. Pernicka, G.A. Wagner, F. Begemann, S. Schmitt-Strecker, C. Eibner, Ö. Oztunali, I. Baranyi

1985 Archäometallurgische Untersuchungen in Nord- und Ostanatolien. Jahrbuch des Römisch-Germanischen Zentralmuseums, Mainz 32: 597-659.

Spooner, E.T.C., and N.H. Gale

$1982 \mathrm{~Pb}$ isotopic composition of ophiolitic volcanogenic sulphide deposits, Troodos Complex, Cyprus. Nature 296: 239-42.

Stech, T,

1989 Nuragic metallurgy in Sardinia. In A. 
Hauptmann, E. Pernicka and G.A. Wagner (eds), Old World Archaeometallurgy. Der Anschnitt Beiheft 7: 39-43. Bochum: Deutsches Bergbau-Museum.

Stos-Gale, Z. A., and N. H. Gale

1992 New light on the provenience of the copper oxhide ingots found on Sardinia. In R. H. Tykot and T. K. Andrews (eds), Sardinia in the Mediternanean: A Footprint in the Sea.

Monographs in Mediterranean Archaeology 3: 317-46. Sheffield: Sheffield Academic Press.

1994 Metals. In A.B. Knapp and J.F. Cherry, Provenience Studies and Bronze Age Cyprus: Production, Exchange and Politico-Economic Change. Monographs in World Archaeology 21: 92-121. Madison: Prehistory Press.

Stos-Gale, Z.A., N.H. Gale and G.R. Gilmore

1984 Early Bronze Age Trojan metal sources and Anatolians in the Cyclades. Oxford Journal of Archaeology 3: 23-43.

Stos-Gale, Z.A., N.H. Gale, and U. Zwicker.

1986 The copper trade in the south-east Mediterranean region: preliminary scientific evidence. Report of the Department of Antiquities, Cypros: 122-44.

Stos-Gale, Z.A. and C.F. Macdonald

1991 Sources of metals and trade in the Bronze Age Aegean. In N.H. Gale (ed.), Bronze Age Trade in the Mediterranean. Studies in Mediterranean Archaeology 90: 249-88. Jonsered: P. Ástroms Förlag.

Tylecote, R.F

1982 The Late Bronze Age: copper and bronze metallurgy at Enkomi and Kition. In J.D. Muhly, R. Maddin and V. Katageorghis (eds), Early Metallurgy in Cyprus 4000-500 BC, 81-100. Larnaca: Pierides Foundarion.

Tylecote, R. F. and Miriam S. Balmuth

1984 Copper and bronze metallurgy in Sardinia. In Miriam S. Balmuth and Robert ]. Rowland, Jr. (eds), Studies in Sardinian Archaeology 1: 115-62. Ann Arbor: University of Michigan.

Tylecote, R. F., H. A. Ghaznavi, and P. J. Boydell

1977 Partitioning of trace elements between the ores, fluxes, slags and metal during the smelting of copper. Journal of Archaeological Science 4: 305-33.

Vagnetti, L. and F. Lo Schiavo

1989 Late Bronze Age long distance trade in the Meditertanean: the role of the Cypriots. In E. Peltenburg (ed.), Early Society in Cypris, 217-43. Edinburgh: Edinburgh University Press.

Yener, K. A., E. V. Sayre, E. C. Joel, H. Ozbal, I. L. Barnes and R. H. Brill

1991 Stable lead isotope studies of central Taurus ore sources and related artifacts from eastern Mediterranean Chalcolithic and Bronze Age sites. Journal of Archaeological Science 18: 541-77,

Zwicker, U.

1986 Ancient metallurgical methods for copper production in Cyprus - Part I. Bulletin 3 , Cyprus Association of Geologists and Mining Engineers, 79-91, Nicosia. 